Family Profile No. 6, 2021

\title{
Homogamy in U.S. Marriages, 2019
}

Author: Lisa Carlson

In the United States, most married couples are homogamous, meaning they share similar characteristics such as educational level

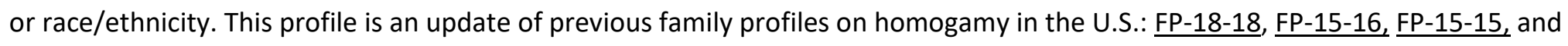
FP-15-14. It investigates educational, racial/ethnic, age, and nativity homogamy among newlyweds (married less than one year) versus those married at least one year, using the 2019 American Community Survey.

\section{Educational Homogamy}

- Among both newlyweds and those married for one year or longer, just over half of couples are homogamous in their educational attainment (the wife and the husband have equal levels of education).

- Educational homogamy is slightly less common among newlyweds (53\%) compared to couples married a year or more (54\%).

- Among couples with educational heterogamy (couples with educational differences), it is more common for wives to have higher levels of education than husbands for both newlyweds and for those married a year or more.

- The proportion of educationally heterogamous couples where the wife has a higher level of education compared to her husband is larger among more recent marriages compared to those married for at least one year $(30 \%$ compared to $25 \%$ ).
Figure 1. Educational Homogamy in U.S. Marriages, 2019

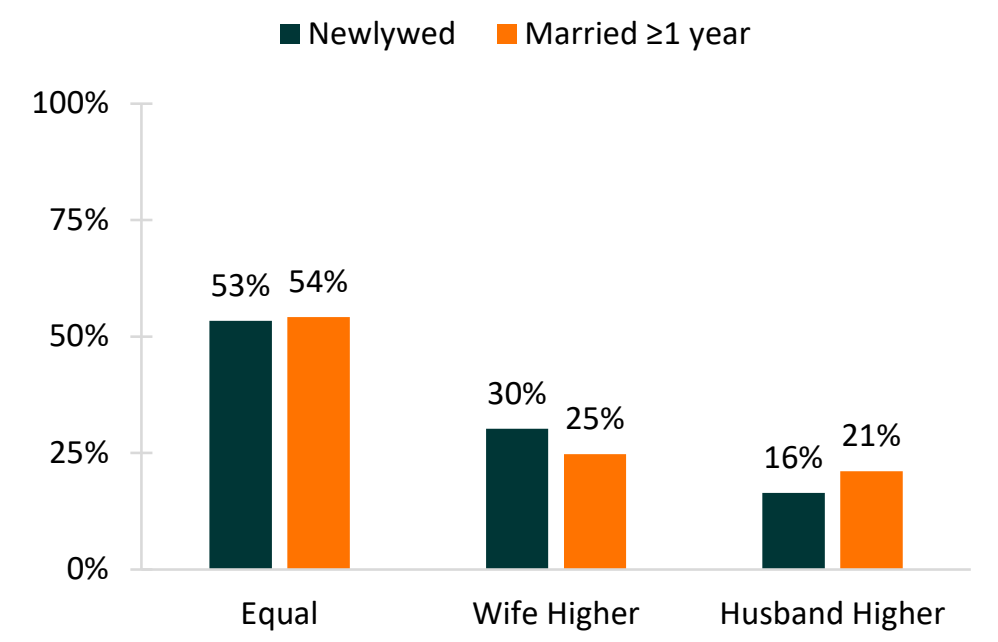

Source: NCFMR analyses of American Community Survey 1-year estimates (IPUMS USA University of Minnesota, www.ipums.org), 2019

\section{Racial/Ethnic Homogamy}

Figure 2. Racial/Ethnic Homogamy in U.S. Marriages, 2019

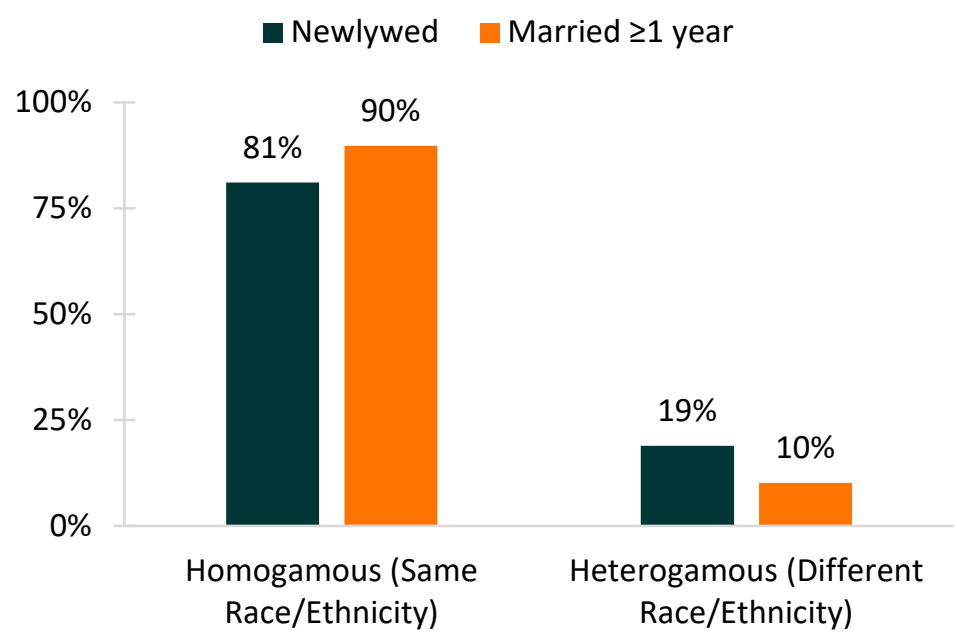

- The majority of couples, both newlyweds and those married at least one year, are in racial/ethnic homogamous marriages.

- The share of heterogamous marriages is higher among newlyweds compared to those married at least one year (19\% compared to $10 \%$ ). 


\section{Spousal Age Homogamy}

- Among both newlyweds and those married at least one year, the majority of couples are approximately the same age $^{1}(60 \%$ and $62 \%$, respectively).

- In couples with age heterogamy (one spouse is two or more years older than the other), the husband is more often the older partner for both newlyweds and those married longer.

- The proportion where the wife is older than the husband is larger for newlyweds compared to those married at least one year ( $17 \%$ compared to $14 \%$ ).

Figure 3. Spousal Age Homogamy in U.S. Marriages, 2019

Newlywed Married $\geq 1$ year

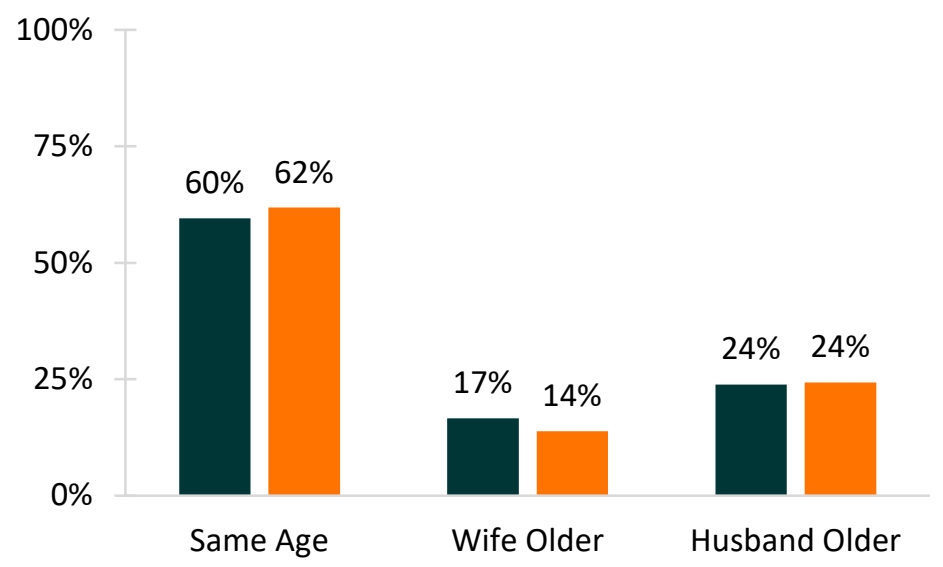

Source: NCFMR analyses of American Community Survey 1-year estimates (IPUMS USA University of Minnesota, www.ipums.org), 2019

\section{Nativity Status in Homogamy}

- In around $90 \%$ of marriages, spouses have the same nativity status - they are either both native born or both foreign born.

- The share of marrieds who are of different nativity status is larger among newlyweds compared to the share of heterogamous couples among those married for a year or more ( $12 \%$ versus $8 \%)$.

Figure 4. Nativity Homogamy in U.S. Marriages, 2019

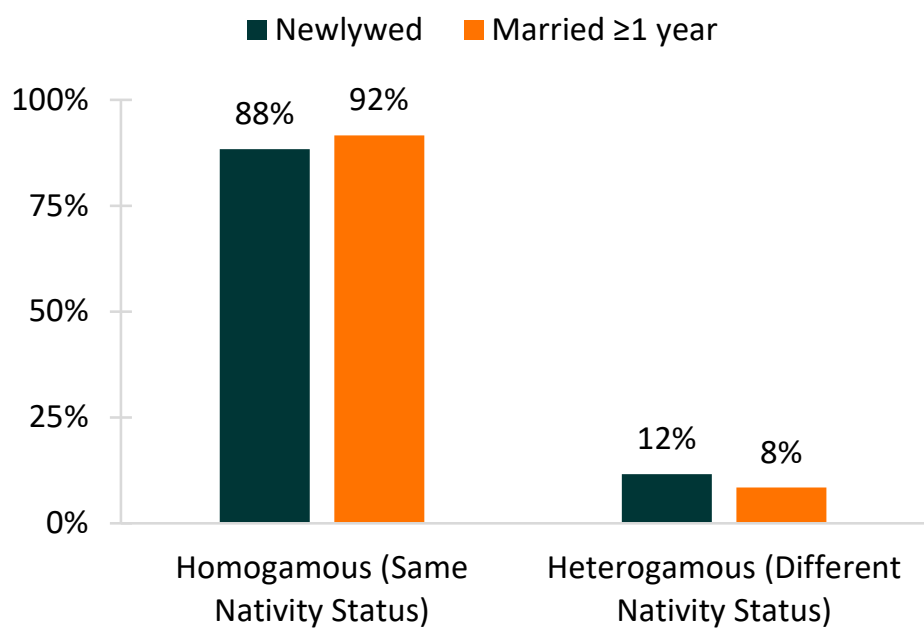

Source: NCFMR analyses of American Community Survey 1-year estimates (IPUMS USA University of Minnesota, www.ipums.org), 2019

\section{Data Sources:}

Ruggles, S. Flood, S., Goeken, R. Grover, J., Meyer, E. Pacas, J. \& Sobek, M. (2020). IPUMS USA: Version 10.0 [dataset]. Minneapolis, MN: IPUMS.

\section{References:}

Lamidi, E., Brown, S. L., \& Manning, W. D. (2015). Assortative mating: Age heterogamy in U.S. marriages, 1964-2014. Family Profiles, FP-15- 14. Bowling Green, $\mathrm{OH}$ : National Center for Family \& Marriage Research. https://www.bgsu.edu/ncfmr/resources/data/family-profiles/lamidi- brown-manning-assortativemating-age-heterogamy-fp-15-14.html

Lamidi, E., Brown, S. L., \& Manning, W. D. (2015). Assortative mating: Educational homogamy in U.S. marriages, 1964-2014. Family Profiles, FP-15-15. Bowling Green, OH: National Center for Family \& Marriage Research. https://www.bgsu.edu/ncfmr/resources/data/family- profiles/lamidi-brown-manningassortative-mating-edu-homogamy-fp-15-15.html

Lamidi, E., Brown, S. L., \& Manning, W. D. (2015). Assortative mating: Racial homogamy in U.S. marriages, 1964-2014. Family Profiles, FP-15- 16. Bowling Green, $\mathrm{OH}$ : National Center for Family \& Marriage Research. https://www.bgsu.edu/ncfmr/resources/data/family-profiles/lamidi- brown-manning-assortativemating-racial-homogamy-fp-15-16.html

Wu, H. (2018). Homogamy in U.S. marriages, 2016. Family Profiles, FP-18-18. Bowling Green, OH: National Center for Family \& Marriage Research. https://doi.org/10.25035/ncfmr/fp-18-18

\section{Suggested Citation:}

Carlson, L. (2021). Homogamy in U.S. Marriage, 2019. Family Profiles, FP-21-06. Bowling Green, OH: National Center for Family \& Marriage Research. https://doi.org/10.25035/ncfmr/fp-21-06 